\title{
Techniques, Indications, and Outcomes in Magnetic Resonance-guided Focused Ultrasound Thalamotomy for Tremor
}

\author{
Satoshi MaeSAWA ${ }^{1,2}$ Daisuke NAKATSubo, ${ }^{2,3}$ Takahiko TsugawA, ${ }^{3}$ \\ Sachiko KATO, ${ }^{2,3}$ Masashi ShIBATA, ${ }^{2,3}$ Sou TAKAI, ${ }^{2}$ Jun TORII, ${ }^{2}$ \\ Tomotaka ISHIZAKI, ${ }^{2,4}$ Toshihiko WAKABAYASHI, ${ }^{2,3}$ and Ryuta SAITO ${ }^{2}$ \\ ${ }^{1}$ Brain and Mind Research Center, Nagoya University, Nagoya, Aichi, Japan \\ ${ }^{2}$ Department of Neurosurgery, Nagoya University Graduate School of Medicine, Nagoya, \\ Aichi, Japan \\ ${ }^{3}$ Radiosurgery and Focused Ultrasound Surgery Center, Nagoya Kyoritsu Hospital, Nagoya, \\ Aichi, Japan \\ ${ }^{4}$ Department of Neurosurgery, Kainan Hospital, Yatomi, Aichi, Japan
}

\begin{abstract}
Magnetic resonance (MR)-guided focused ultrasound surgery (MRgFUS) is the latest minimally invasive stereotactic procedure, and thalamotomy using this novel modality has demonstrated its effectiveness and safety, especially for patients with essential tremor (ET) and Parkinson's disease (PD). In Japan, the application of MRgFUS to treat ET and PD has recently been covered by health insurance. Technically, the transducer with 1024 elements emits ultrasound beams, which are then focused on the target with a phase control, resulting in optimal ablation by thermal coagulation. The technical advantages of MRgFUS are continuous intraoperative monitoring of clinical symptoms and MR images and fine adjustment of the target by the steering function. Postoperative tremor control is compatible with other modalities, although long-term follow-up is necessary. The adverse effects are usually transient and acceptable. Prognostic factors for good tremor control include high temperature and large lesion size. A high skull density ratio is a factor to achieve high temperature and large lesioning, but it may not be necessary and sufficient for clinical outcomes. For patients with advanced symptoms such as bilateral tremor or head/neck tremor, deep brain stimulation may be recommended because of the adjustability of stimulation and the possibility of bilateral treatment. Patients have high expectations of MRgFUS because of its non-invasiveness. To perform this treatment safely and effectively, physicians need to understand the technological aspects, the physiological principles. To choose the appropriate modality, physicians also should recognize the clinical advantages and disadvantages of MRgFUS compared to other modalities.
\end{abstract}

Keywords: MR-guided focused ultrasound therapy (MRgFUS), thalamotomy, essential tremor, Parkinson's disease

\section{Introduction}

Magnetic resonance (MR)-guided focused ultrasound surgery (MRgFUS) is a novel method of neuromodulation in the field of stereotactic functional

Received June 6, 2021; Accepted July 26, 2021

Copyright $@ 2021$ The Japan Neurosurgical Society This work is licensed under a Creative Commons AttributionNonCommercial-NoDerivatives International License. neurosurgery. This method focuses on multiple extracranial ultrasonic waves on the target inside the brain, by controlling the phase and amplitude to oscillate multiple waves under the guidance of structural and thermal images obtained by MRI. Although it requires the attachment of a head frame, it does not require a skin incision or trepanation. Therefore, it is a truly less-invasive brain surgery method. Its device (ExAblate 4000, InSightec, Tirat Carmel, Israel), developed in Israel and approved by the FDA in the United States in July 2016, is widely available. Pharmaceutical 


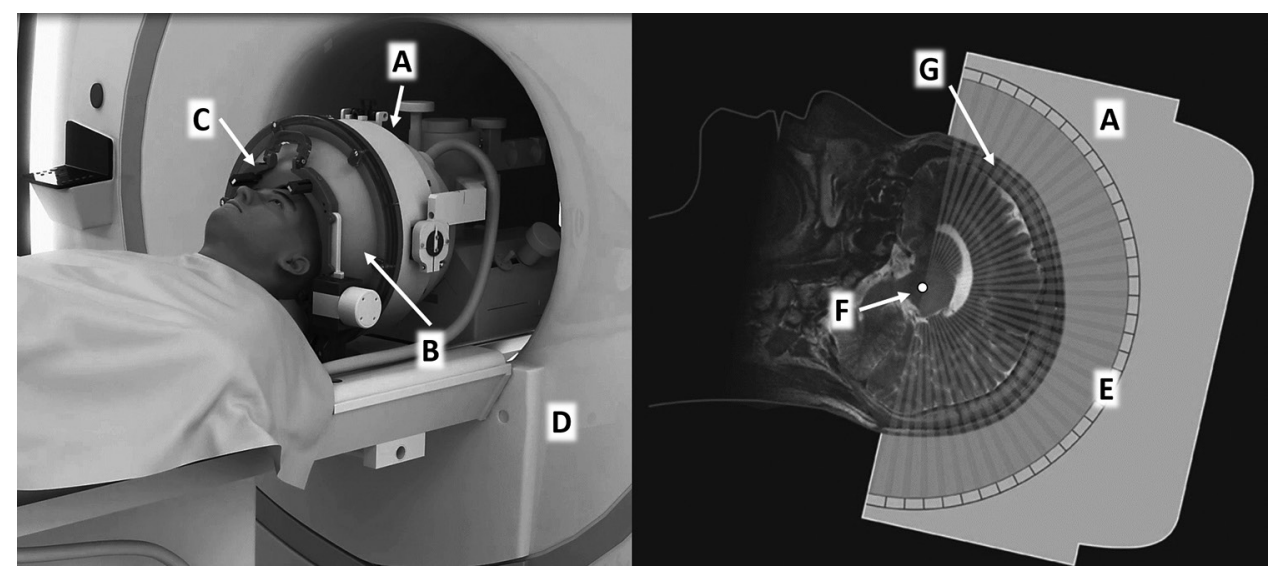

Fig. 1 Illustration of MRgFUS. The beams of ultrasound emerge from the transducer (A) with 1024 elements (E) and are focused on the target (F) under the guidance of MRI (D). Degassed chilled water is circulated inside the space between the membrane (B) and the scalp (G) of the patient. (A) Phased-array transducer, (B) membrane, (C) stereotactic frame, (D) MRI scanner, (E) elements, (F) target, and (G) scalp. (Original illustrations are provided by InSightec.) MRgFUS: Magnetic resonance-guided focused ultrasound surgery.

approval was obtained in Japan in the same year for the treatment of essential tremor (ET). The Japanese health insurance covered this treatment for ET in June 2019 and Parkinson's disease (PD) in September 2020. ${ }^{1)}$ Considering the historical background of functional neurosurgery, stereotactic thermal ablation using a radiofrequency (RF) probe has been widely used since the 1950s, but it has been replaced by deep brain stimulation (DBS) since the 1990s. $\left.{ }^{2}\right)$ This was because DBS had great advantages such as reversibility and adjustability for the target, while RF ablation simply made an irreversible lesion by coagulating the tissue. However, with the advent of MRgFUS, ${ }^{3,4)}$ stereotactic lesioning has received renewed attention. Noninvasiveness and good outcomes in this novel modality are driving this trend; however, DBS has recently been criticized for undesirable complications such as hardware-related infection.. ${ }^{5}$ Is MRgFUS a treatment that surpasses DBS? What is the difference between MRgFUS and conventional RF ablation? How do physicians choose the preferred modality for patients? To answer these questions, we first describe the physical principles of the technology in MRgFUS and explain the treatment procedure using MRgFUS based on our clinical experience. Then, we review the literature for clinical outcomes and factors associated with prognosis. We also discuss optimal indications compared with other modalities.

\section{Physical Principles in Technology for MRgFUS}

Ultrasound is defined as an inaudible sound with a frequency of $20000 \mathrm{~Hz}$ or higher. It is characterized by a short wavelength and strong directivity and is used in sonar (fish-finders), depth sounders, and medical ultrasonic inspections. It also has the feature of the heat of absorption being readily adjustable by the sound pressure; therefore, it is also used for ultrasonic cleaning and cutting jewelry and glass. The piezoelectric effect is useful in transducers for generating and detecting ultrasound waves in air and water. ${ }^{6)}$ Taking advantage of these characteristics, in focused ultrasound therapy, a hemispherical helmet-type transducer equipped with 1024 ultrasound emerging elements (piezoelectric elements) is attached to the patient's head, and then, by electronically controlling the frequency, phase, and amplitude of the wave from each element, energy is focused on the preoperatively planned target to create a thermally coagulated lesion (Fig. 1). ${ }^{7)}$

The first half of the sound path, from the element of the transducer to the scalp, is filled with degassed and chilled water. If there are bubbles in the path, cavitation, i.e., the collapse of bubbles, will occur and cause unexpected energy release, high temperature, and high pressure (up to $5000^{\circ} \mathrm{C}, 2000 \mathrm{~atm}$ ). Shaving the patient's head is also necessary to avoid creating bubbles. Continuous cooling by circulated and chilled water is necessary because of the heat of absorption on the scalp.

The skull is the largest barrier in the second half of the sound path. It is 20-50 times more absorptive than other soft and brain tissues ${ }^{8)}$ and is mostly reflected at incidence angles larger than $35^{\circ}$. The skull density ratio (SDR) is an important factor for ultrasound passing through the skull; the higher 


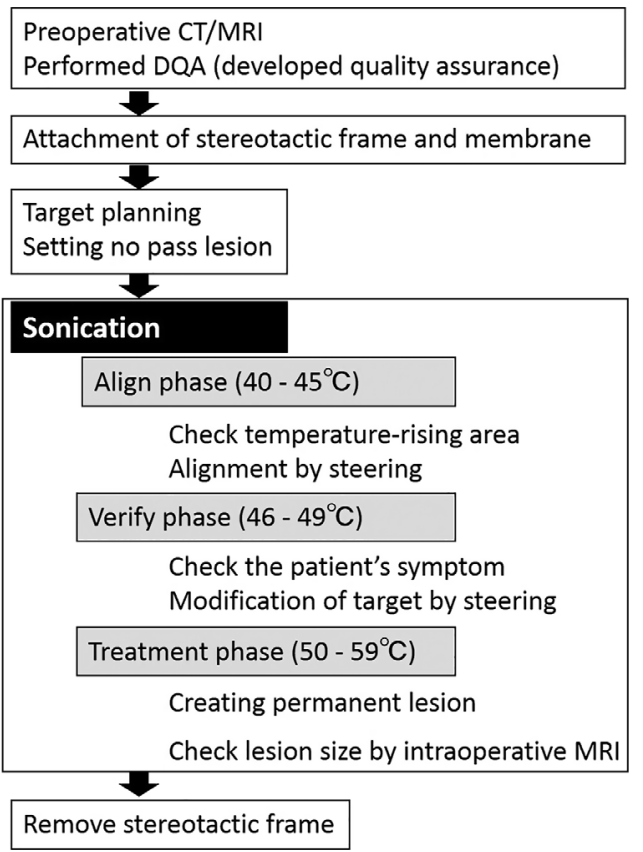

Fig. 2 A workflow of MRgFUS. MRgFUS: Magnetic resonance-guided focused ultrasound surgery.

the SDR, the easier it is for ultrasound waves to pass through the skull. An adjustment of the rising temperature at the focus is the main part of this technology and is achieved by a phase correction from CT profiles of the skull thickness, shape, and SDR and from calculation of loss of energy by absorption; thus, the target energy is focused on a region of approximately $1.0 \times 1.0 \times 3.0 \mathrm{~mm}$. Thermal MR images are used to continuously monitor the temperature of the target tissue. ${ }^{9)}$ With this, the relative temperature change can be measured by utilizing the physical phenomenon that the proton resonance frequency slightly shifts according to the temperature rise $\left(0.01 \mathrm{ppm} /{ }^{\circ} \mathrm{C}\right)$, assuming that the equilibrium temperature of the soft tissue is $37^{\circ} \mathrm{C}$. Middle and high frequencies $(650-670 \mathrm{kHz})$ are used for stereotactic coagulation of small targets, such as thalamotomies. On the contrary, low-frequency devices $(220 \mathrm{kHz})$ are used in combination with microbubbles to open the blood-brain barrier in a relatively wide area. Many studies on MRgFUS application in drug delivery are currently ongoing. ${ }^{10-12)}$ Ultrasound irradiation is called "sonication" to distinguish it from radiation.

\section{Treatment Procedures}

An outline of the treatment procedure is shown in Fig. 2. On the day prior to treatment, head CT and MRI are performed for treatment planning.
Development quality assurance is routinely performed using a phantom in every case. On the treatment day, the patient's head is shaved. A stereotactic frame (Cosman-Roberts-Wells head frame; Radionics, Dublin, Ireland) is attached to the head under local anesthesia. To increase the sonicated area, the head pins are fixed as low as possible (approximately 2 $\mathrm{cm}$ above the upper edge of the orbit and just above the attachment of the posterior cervical muscles). A membrane shaped like a shampoo hat is also carefully attached to the head as low as possible to prevent air bubbles between it and the skin. The patient then enters the MR imaging room and lays down on the bed; the transducer is then connected to the attachment device of the membrane. Degassed chilled water is circulated inside the membrane to maintain the temperature below $19^{\circ} \mathrm{C}$.

Subsequent operations are performed using the MRgFUS workstation ExAblate Neuro (InSightec). The location of the center of the transducer and the central frequency of the MRI are determined. Structural MRI (T1) is performed, and the anterior commissure (AC) and posterior commissure (PC) are determined. 3D (axial, coronal, and sagittal) T1 images are taken with reference to the AC-PC line. Preoperative CT images are fused to the obtained MR images. Calcification and the remaining air between the membrane and the skin are contoured as a no-pass region, and several markers are designated for movement detection.

In thalamotomy for tremors, the target is the ventral intermediate nucleus (Vim), although the setting is slightly different among institutions. In our institution, the initial target is set at $15-17 \mathrm{~mm}$ lateral from the midline $(12 \mathrm{~mm}$ lateral from the outer wall of the third ventricle), the distance of one-third AC-PC minus $1.5 \mathrm{~mm}$ (1/3 AC-PC-1.5 mm) anterior from the $\mathrm{PC}$, and $1.5-2.0 \mathrm{~mm}$ above the AC-PC plane. In RF thalamotomy, it is necessary to consider the angle of the inserted probe and the distance between the initial target corresponding to the deepest part and the coagulation sites, but this is unnecessary in MRgFUS. The lateral, posterior, and lower parts of the Vim are known to be effective in suppressing tremor. ${ }^{13-15)}$ However, there is a pyramidal tract on the lateral side, and lesioning here has a risk of motor paresis. The ventral caudal nucleus in the posterior site is also associated with a risk of sensory impairment of the tongue, mouth, face, and hand after lesioning. In particular, it is difficult to improve taste disturbance once it occurs. The lower part is the posterior subthalamic area, including the zona incerta and the prelemniscal radiation (RaprL) bundles, which consist of the dentato-rubro-thalamic tract and pallidothalamic 
fibers. ${ }^{16)}$ While this area can be expected to suppress tremors, walking disturbance can be caused by hypotonia of the lower limbs. ${ }^{17)}$ Intraoperative MRI can be performed. MRI showed a signal change with a diameter of 4-5 mm immediately after treatment, which may increase to $8-10 \mathrm{~mm} 24$ hours to 1 week later, although the diameter of the final lesion becomes $1 \mathrm{~mm}$ or less after 3 months or later. ${ }^{18)}$ Although there is still no consensus on how large a lesion should be in MR images obtained during the procedure, we attempted to create a sufficiently large lesion while avoiding the pyramidal tract and the VC. We usually set up the initial target $2 \mathrm{~mm}$ apart from these structures.

At the beginning of sonication, low energy is applied to reach the temperature of $40-45^{\circ} \mathrm{C}$. This process is called as "align phase," and it would confirm whether the actual target site has a temperature rise. By increasing the power to reach a moderate temperature $\left(46-50^{\circ} \mathrm{C}\right)$, the patient's symptoms are checked, which are usually reversible at these temperatures (verify phase). After confirming the suppression of tremor without any complications, the temperature is increased to $55-59^{\circ} \mathrm{C}$ (treatment phase). Note that the temperature is lower than that in RF thalamotomy. This is because the heat generated by ultrasound is physically different from the heat conduction by the RF probe and has different effects on the tissue. Setting the parameters for sonication, including energy, power, and duration, is necessary and requires some experience. The monitoring of cavitation is also important. The current workstation has a function that automatically lowers the power for safety when cavitation frequently occurs. During the procedure, the system continuously monitors subtle movement of the patient's head by several markers designated for movement detection in the planning phase, as described earlier. Continuous communication should be performed with the patient during the procedure, and symptomatic changes should be checked at every step using the finger-nose test and spiral drawing in a lying position. Adverse effects (numbness, headache, and muscle weakness) should also be checked frequently. In the case of a patient with low SDR, it is difficult to reach a high temperature; therefore, a large amount of energy and long sonication are required. In such cases, the patient often complains of headache. Side effects, such as swelling of the scalp and face, were also observed after treatment. A combination of analgesics should be administered if necessary. During the procedure, fine adjustment of the target is possible with a distance of less than $1 \mathrm{~mm}$. This is a great advantage of MRgFUS, called the steering function, which enables the focus to move $1 \mathrm{~mm}$ or less by the phase control of each element. It is usually impossible to adjust the position of the probe or electrode on a submillimeter scale in RF thalamotomy or DBS.

\section{Clinical Indication of MRgFUS}

Currently, the Japanese health insurance covers MRgFUS for ET and PD. Two indications are specified in the Japanese guidelines, "2019 New medical device fair use standard MRgFUS development project report"19): 1) control of tremor in patients with ET or PD, which is not sufficiently controlled by medication, targeting the thalamus and 2) alleviation of motor symptoms in patients with $\mathrm{PD}$, which are not sufficiently controlled by medication, targeting the globus pallidum interna (GPi) nuclei. However, MRgFUS is limited in cases where DBS is not suitable, such as in those at an old age, having a risk of general anesthesia, requiring regular MRI examinations, or working in places with high magnetic fields.

Although surgical invasion is minimal in MRgFUS, the following points should be noted. In terms of age, patients should be at least 18 years old, because younger patients and children lack experience. A history of implantation of metallic devices and claustrophobia is contraindicated as in the case of MRI scanning. The patients are required to lie supine in the scanner for 2 to 3 hours and to communicate during the procedures. Bleeding tendency and coagulation dysfunction should be excluded from the criteria. Patients with a history of craniotomy should also be excluded because phase correction using CT profiles can be inaccurate.

In many studies, including the MRgFUS pilot study, SDR was considered to be an important factor; therefore, an SDR of less than 0.45 was set as an exclusion criterion., ${ }^{3,2021)}$ However, some reports insisted that patients with a low SDR were less likely to have an increase in target temperature, but the improvement rate of tremor itself was not affected. ${ }^{22-24)}$ The SDR of Asians is generally lower than that of Westerners. ${ }^{25}$ We consider SDRs above 0.35 to be acceptable, but we do not recommend MRgFUS for patients with an SDR below 0.30. Treatment decisions should be made after adequate information has been provided for patients with a low SDR.

Accurate diagnosis of ET is necessary, distinguishing it from physiological tremor, thyroid disease, or other neurodegenerative diseases. The International Parkinson and Movement Disorder Society proposed a consensus statement on the classification of tremors in $2018,{ }^{26)}$ in which ET is defined as follows: 
1) isolated tremor syndrome of bilateral upper limb action tremor, 2) having at least 3 years duration, (3) with or without tremor in other locations (e.g., head, voice, lower limbs), and (4) absence of other neurological signs, such as dystonia, ataxia, and Parkinsonism. Essential tremor plus (ET-plus) is accompanied by other neurological findings such as impaired tandem gait, dystonia posturing, and mild memory loss. ET with resting tremor was also indicated as ET-plus. There is a criticism that this concept is not based on pathological or prognostic aspects and may simply be an advanced condition of ET. ${ }^{27)}$ A report comparing the clinical outcomes after DBS between patients with ET and ET-plus concluded that there was no significant difference between the two groups, but those with ET-plus required higher stimulation intensity and dorsal stimulation. ${ }^{28)}$ It is interesting to see if there is a difference in clinical outcomes after MRgFUS between ET and ET-plus.

For PD, as described earlier, thalamotomy for suppressing tremor and pallidotomy to improve other symptoms, including dyskinesia, are indicated for MRgFUS according to the Japanese guidelines. At present, this treatment is covered by Japanese health insurance only on the unilateral side; therefore, a good indication may be restricted to patients with unilaterally dominant symptoms. $\mathrm{PD}$ is a progressive and systemic functional disorder that is characterized by cognitive symptoms, autonomic symptoms, and psychiatric symptoms in addition to motor symptoms. Considering the impairment of quality of life caused by various symptoms in PD, the clinical significance of MRgFUS, which aims to improve unilateral movement, remains questionable. However, since this treatment has a small burden on the patient, there is a chance to improve the quality of life in some cases with limited symptoms, such as tremor-dominant PD. ${ }^{29)}$ Sufficient information about MRgFUS treatment should be provided to these patients to explain which symptoms improve and which symptoms persist.

\section{Outcomes and Safety of MRgFUS: Can MRgFUS Surpass DBS?}

Thalamotomy for ET using MRgFUS was the first application in clinical practice, and according to personal communication with InSightec, there were already more than 4000 cases treated worldwide by the end of 2020. A pilot study of this treatment was first reported by Elias et al., from the University of Virginia in 2013, and its safety and effectiveness have been well demonstrated in randomized trials in 2016.3.4) Our team (Department of
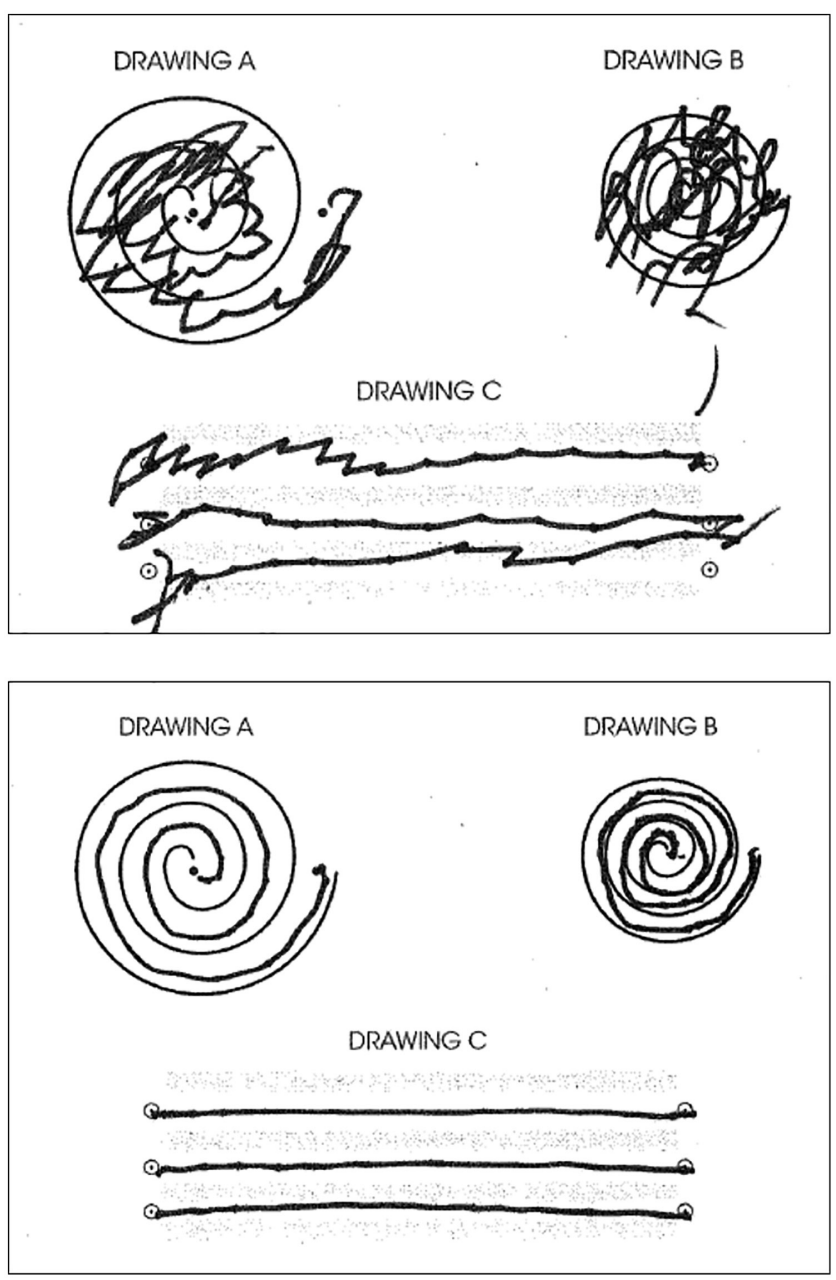

Fig. 3 Drawing spirals and lines in the CRST testing. Upper: preoperative drawing. Lower: postoperative drawing. CRST: clinical rating scale of tremor.

Neurosurgery, Nagoya University Graduate School of Medicine and Focused Ultrasound Surgery Center, Nagoya Kyoritsu Hospital, Japan) started MRgFUS for ET in 2017 and has experienced more than 80 cases by December 2020. The improvement rate of the clinical rating scale of tremor (CRST) at 6 months was approximately $68.5 \%$ (unpublished data; details will be reported elsewhere) (Fig. 3). Representative publications on clinical outcomes and associated factors in MRgFUS for ET are summarized in Table 1. According to a multicenter clinical study by Chang et al., ${ }^{30)}$ the improvement rate of CRST was $55 \%$ at 6 months and $56 \%$ after 2 years. They concluded that the therapeutic effect at 6 months could be expected to remain for at least 2 years. Side effects included sensory disturbance, taste disturbance, gait disturbance, ataxia, and dizziness, all of which were transient and almost disappeared within a year. Similar results were 
Table 1 Clinical outcomes and associated factors in MRgFUS for patients with ET

\begin{tabular}{|c|c|c|c|c|c|c|c|c|}
\hline Authors & $\begin{array}{l}\text { Pub. } \\
\text { year }\end{array}$ & Country & $\begin{array}{l}\text { N. of } \\
\text { Pts }\end{array}$ & $\begin{array}{l}\mathrm{F} / \mathrm{U} \\
(\mathrm{M})\end{array}$ & $\begin{array}{l}\text { Tremor imp. } \\
\text { rate in treated } \\
\text { UE, \% (at } \\
\text { when) }\end{array}$ & $\begin{array}{l}\text { General } \\
\text { tremor imp. } \\
\text { rate, \% (at } \\
\text { when) }\end{array}$ & Adverse effects & $\begin{array}{l}\text { Prognostic factors } \\
\text { for good tremor } \\
\text { control }\end{array}$ \\
\hline $\begin{array}{l}\text { Elias } \\
\text { et al. }{ }^{3)}\end{array}$ & 2013 & USA & 15 & 12 & $75 \%(12 \mathrm{M})$ & $56 \%(12 \mathrm{M})$ & $\begin{array}{l}\text { Paresthesia, dysesthesia, } \\
\text { ataxia, dysmetria, } \\
\text { slurred speech }\end{array}$ & N/A \\
\hline $\begin{array}{l}\text { Elias } \\
\text { et al.4) }\end{array}$ & 2016 & $\begin{array}{l}\text { Multi- } \\
\text { center }\end{array}$ & 56 & 3 & $\begin{array}{l}55 \%(3 \mathrm{M}), \\
52 \%(6 \mathrm{M})\end{array}$ & $\begin{array}{l}41 \%(3 \mathrm{M}) \\
35 \%(12 \mathrm{M}) \\
\text { sham, } 2 \% \\
(3 \mathrm{M})\end{array}$ & $\begin{array}{l}\text { Paresthesia, taste } \\
\text { disturbance, gait } \\
\text { disturbance, dysmetria, } \\
\text { weakness, headache }\end{array}$ & $\mathrm{N} / \mathrm{A}$ \\
\hline $\begin{array}{l}\text { Chang } \\
\text { et al. }{ }^{30)}\end{array}$ & 2018 & $\begin{array}{l}\text { Multi- } \\
\text { center }\end{array}$ & 76 & 24 & $\begin{array}{l}55 \%(6 \mathrm{M}) \\
53 \%(12 \mathrm{M}) \\
56 \%(24 \mathrm{M})\end{array}$ & N/A & $\begin{array}{l}\text { Paresthesia, gait } \\
\text { disturbance, taste } \\
\text { disturbance, dysergia, } \\
\text { dysmetria, weakness, } \\
\text { dizziness, headache }\end{array}$ & N/A \\
\hline $\begin{array}{l}\text { Meng } \\
\text { et al. }{ }^{31)}\end{array}$ & 2018 & Canada & 37 & 24 & $\begin{array}{l}42 \%(12 \mathrm{M}), \\
43 \%(24 \mathrm{M})\end{array}$ & N/A & $\begin{array}{l}\text { Weakness, ataxia, } \\
\text { disequilibrium , } \\
\text { dysarthria, dysphagia }\end{array}$ & $\begin{array}{l}\text { Large lesion volume } \\
\text { (1 day after), } \\
\text { younger age }\end{array}$ \\
\hline $\begin{array}{l}\text { Park } \\
\text { et al. }{ }^{32)}\end{array}$ & 2019 & Korea & 15 & 48 & $\begin{array}{l}71 \%(6 \mathrm{M}), \\
70 \%(12 \mathrm{M}), \\
60 \%(24 \mathrm{M}), \\
56 \%(48 \mathrm{M})\end{array}$ & N/A & $\begin{array}{l}\text { Dizziness, nausea, } \\
\text { paresthesia in the } \\
\text { tongue, balance } \\
\text { impairment }\end{array}$ & N/A \\
\hline $\begin{array}{l}\text { Sinai } \\
\text { et al. }\end{array}$ & 2019 & Israel & 44 & 12 & $79 \%(12 \mathrm{M})$ & $61 \%(12 \mathrm{M})$ & $\begin{array}{l}\text { Ataxia (gait, hand), } \\
\text { dysgeusia, paresthesia } \\
\text { (lip tongue, hand) }\end{array}$ & $\begin{array}{l}\text { High SDR. } \\
\text { Big number of } \\
\text { sonication }\end{array}$ \\
\hline $\begin{array}{l}\text { Boutet } \\
\text { et al. }{ }^{22)}\end{array}$ & 2019 & Canada & 98 & 3 & $\begin{array}{l}53 \%(3 \mathrm{M}), \\
45 \%(12 \mathrm{M})\end{array}$ & N/A & $\begin{array}{l}\text { Sensory disturbance, } \\
\text { motor weakness, ataxia, } \\
\text { speech disturbance }\end{array}$ & $\begin{array}{l}\text { SDR is not a } \\
\text { prognostic factor }\end{array}$ \\
\hline $\begin{array}{l}\text { D’Souza } \\
\text { et al. }{ }^{23)}\end{array}$ & 2019 & $\begin{array}{l}\text { Multi- } \\
\text { center }\end{array}$ & 189 & 12 & $\begin{array}{l}\text { SDR }<4,46 \% \\
(12 \mathrm{M}) ; \mathrm{SDR}= \\
0.4-0.45,63 \% \\
(12 \mathrm{M}) ; \mathrm{SDR} \\
>0.45,58 \%(12 \\
\mathrm{M})\end{array}$ & N/A & $\begin{array}{l}\mathrm{SDR}<4,40 \% ; \mathrm{SDR}= \\
0.4-0.45,45 \% ; \mathrm{SDR} \\
>0.45,63 \%\end{array}$ & $\begin{array}{l}\text { SDR is not a } \\
\text { prognostic factor }\end{array}$ \\
\hline $\begin{array}{l}\text { Krishna } \\
\text { et al. }{ }^{33)}\end{array}$ & 2020 & $\begin{array}{l}\text { Multi- } \\
\text { center }\end{array}$ & 179 & 12 & $\begin{array}{l}61 \%(3 \mathrm{M}), \\
58 \%(12 \mathrm{M})\end{array}$ & N/A & $\begin{array}{l}\text { Balance or gait } \\
\text { disturbance, dysmetria/ } \\
\text { ataxia/dizziness, sensory } \\
\text { disturbance, speech } \\
\text { disturbance, weakness }\end{array}$ & $\begin{array}{l}\text { High peak } \\
\text { temperature, post } \\
\text { pivotal treatment } \\
\text { cohort (yes), } \\
\text { younger age, short } \\
\text { disease duration, } \\
\text { small number of } \\
\text { sonication }\end{array}$ \\
\hline $\begin{array}{l}\text { Pineda- } \\
\text { Pardo } \\
\text { et al. }{ }^{34)}\end{array}$ & 2020 & Spain & 39 & 12 & $\begin{array}{l}83 \%(3 \mathrm{M}), \\
76 \%(12 \mathrm{M})\end{array}$ & $\begin{array}{l}57 \%(3 \mathrm{M}) \\
53 \%(12 \mathrm{M})\end{array}$ & $\begin{array}{l}\text { Subjective instability, } \\
\text { gait ataxia. Largest } \\
\text { lesions accounted for } \\
\text { the occurrence of gait } \\
\text { imbalance }\end{array}$ & $\begin{array}{l}\text { Large lesion } \\
\text { volume, occupancy } \\
\text { of the Vim, more } \\
\text { posterior and } \\
\text { inferior lesion }\end{array}$ \\
\hline $\begin{array}{l}\text { Abe } \\
\text { et al. }{ }^{25)}\end{array}$ & 2021 & Japan & 35 & 12 & $\begin{array}{l}57 \%(3 \mathrm{M}), \\
56 \%(12 \mathrm{M})\end{array}$ & $\begin{array}{l}44 \%(3 \mathrm{M}), \\
43 \%(12 \mathrm{M})\end{array}$ & $\begin{array}{l}\text { Hemiparesis, dysarthria, } \\
\text { dysphagia, gait } \\
\text { disturbance, unsteady } \\
\text { gait, hypotonia, } \\
\text { numbness, facial edema, } \\
\text { dizziness }\end{array}$ & None \\
\hline
\end{tabular}

ET: essential tremor, F/U: follow-up, imp.: improvement, M: month, MRgFUS: magnetic resonance-guided focused ultrasound surgery, N of Pts: number of patients, N/A: not attributed, Pub: publication, SDR: skull density ratio, UE: upper extremity, Vim: ventral intermediate. 
reported by the University of Toronto. ${ }^{31)}$ In clinical practice, we realize that recurrence of tremor is sometimes seen during the first year after treatment, but stable effectiveness is observed thereafter. Park et al. recently summarized 4-year follow-up results after MRgFUS for ET and reported that a $56 \%$ improvement in CRST was maintained even after 4 years, although the number of patients was small $(n=15) .{ }^{32}$ Further studies are necessary to evaluate long-term outcomes.

High peak temperature, younger age, and short duration of disease have been reported as prognostic factors, but it remains controversial whether SDR is a prognostic factor. ${ }^{21-23,33)}$ Lesion size and location are also important prognostic factors. ${ }^{34,35)}$ Pineda-Pardo et al. reported that the greatest clinical improvement correlated with a larger lesion volume and a more inferior and posterior location, whereas the largest lesion accounted for the occurrence of gait disturbance. ${ }^{34)}$ From our experience, we realize that we can readily reach high temperatures if the SDR is high enough to generate larger lesions. However, even if the SDR is relatively low, we may still generate large lesions by increasing the energy and the number of sonication cycles. Recently, Yamamoto et al. reported that the temperature increase should be set to the least value in the alignment and verification phases, and subsequently should be increased in the treatment phase, to maximize the heating efficacy. Such a management can contribute to increase the temperature for the patients with a low SDR. ${ }^{36)}$ Therefore, a high SDR may not be necessary or sufficient to achieve satisfactory suppression of tremors.

For PD, several targets have been designed for MRgFUS (Table 2). Magara et al. reproved the pallidothalamic tractotomy (PTT) ${ }^{37)}$ The target is in the subthalamic area, the center of a fiber bundle connecting the pallidum and thalamus. The pallidothalamic fibers of the fasciculus lenticularis (Forel $\mathrm{H} 2$ ) and the ansa lenticularis come to this area and are funneled together into the thalamus. ${ }^{38)}$ They reported a good reduction in the motor score of the Unified Parkinson's Disease Rating Scale (UPDRS), $60.9 \%$ postoperatively. Vim is a promising target for tremor relief in patients with tremor-dominant PD. Good results have been reported in randomized trials by Bond et al. ${ }^{29)}$ In their report, the tremor scale improved by $62 \%$ in the MRgFUS group and by $22 \%$ in the sham treatment group. Pallidotomy using MRgFUS has also been reported, and it demonstrated good control for dyskinesia-dominant PD ${ }^{39)}$ Furthermore, a clinical trial of subthalamotomy using MRgFUS is ongoing. ${ }^{40)}$ Lesioning the subthalamic nucleus (STN) has been avoided in the past due to serious complications such as chorea, ballismus, dyskinesia, and dysarthria. ${ }^{41,42)}$ However, in their pilot study, ${ }^{40)}$ the target was slightly dorsolateral to the conventional localization of the STN. No serious side effects were observed in their study, and this may be reflected by such a small difference in localization. The motor score of the UPDRS improved postoperatively by $53 \%$ during on-medication and by $47 \%$ during off-medication. Randomized control for subthalamotomy has recently been reported, demonstrating promising results. ${ }^{43}$

Can MRgFUS surpass DBS? A recent review from the University of Toronto compared treatment outcomes for ET among four different surgical procedures, including DBS, radiosurgery, RF, and MRgFUS. ${ }^{44)}$ Overall, all modalities reported reasonable outcomes with no significant differences in tremor control. When examined in detail, bilateral DBS demonstrated greater improvement in tremor reduction, ranging from $66 \%$ to $78 \%$. This is because both upper limbs can be treated, and bilateral DBS may possibly control the head, neck, and voice tremor. ${ }^{45,46)}$ When limited to unilateral treatment, $\mathrm{RF}$ thalamotomy is more effective in suppressing tremors than DBS. ${ }^{47,48)}$ However, for long-term (5 years or more) tremor control, DBS is the best treatment option (60-75\%)..4950) The adjustability of DBS may be the reason for this. On the contrary, there is criticism for MRgFUS that the recurrence rate may be higher than others. There have been few reports on the long-term outcomes of MRgFUS; therefore, further evaluation is warranted. Gait disturbance and ataxia are frequently reported during $\mathrm{RF}$ thalamotomy. The most common issues for DBS are surgical site infection and hardware problems, which account for $1.4-5.4 \%$ of cases., ${ }^{5,51)}$ Simply looking at the number, the occurrence of such infection or hardware problems is not high, but in cases where it occurs, the entire system of implanted DBS, which places a heavy burden on the patient, should be removed. Considering these comparisons, DBS may be the most recommended treatment at present, especially for severe ET. However, patients have high expectations of MRgFUS because it uses relatively clean energy and does not require skin incision, trepanation, or intracranial insertion. Physicians need to understand the pros and cons of each procedure and provide sufficient information to patients. Several studies are in progress for new applications of MRgFUS, including in psychiatric diseases such as obsessive-compulsive disorder, ${ }^{52)}$ dystonia ${ }^{53)}$ epilepsy, ${ }^{54)}$ and Alzheimer's disease. ${ }^{12)}$ MRgFUS should continue to be developed in the treatment of ET and PD, and its indications for other diseases should be expanded. 
Table 2 Representative studies in the application of MR-guided focused ultrasound in PD

\begin{tabular}{|c|c|c|c|c|c|c|c|c|}
\hline Authors & $\begin{array}{l}\text { Pub. } \\
\text { year }\end{array}$ & Country & $\begin{array}{l}\text { N. of } \\
\text { Pts }\end{array}$ & $\begin{array}{l}\mathrm{F} / \mathrm{U} \\
(\mathrm{M})\end{array}$ & $\begin{array}{c}\text { Patient's } \\
\text { characteristics }\end{array}$ & Target & Improvement & Adverse effects \\
\hline $\begin{array}{l}\text { Magara } \\
\text { et al. }{ }^{37)}\end{array}$ & 2014 & Switzerland & 14 & 3 & $\begin{array}{l}\text { Tremor } \\
\text { dominant } \\
(7 / 14) \text {, tremor - } \\
\text { akinesia }(4 / 14) \text {, } \\
\text { dyskinesia } \\
(4 / 14)\end{array}$ & PTT & $\begin{array}{l}60.9 \% \text { reduction in } \\
\text { UPDRS }(3 \mathrm{M})\end{array}$ & None \\
\hline $\begin{array}{l}\text { Bond } \\
\text { et al. }{ }^{29)}\end{array}$ & 2017 & USA & 27 RCT & 3 & $\begin{array}{l}\text { Tremor } \\
\text { dominant }\end{array}$ & Vim & $\begin{array}{l}62 \% \text { reduction } \\
\text { in CRST on } \\
\text { medication ( } 3 \mathrm{M}) \text {, } \\
\text { sham, } 22 \% ; 34.7 \% \\
\text { reduction in UPDRS } \\
\text { III on medication ( } 3 \\
\text { M), sham, } 4 \%\end{array}$ & $\begin{array}{l}\text { Hemiparesis, } \\
\text { orofacial } \\
\text { paresthesia, } \\
\text { finger } \\
\text { paresthesia, } \\
\text { ataxia }\end{array}$ \\
\hline $\begin{array}{l}\text { Jung } \\
\text { et al. }{ }^{39)}\end{array}$ & 2018 & Korea & 8 & 6 & $\begin{array}{l}\text { Dyskinesia } \\
\text { dominant }\end{array}$ & GPi & $\begin{array}{l}32.2 \% \text { reduction } \\
\text { in UPDRS III on } \\
\text { medication }(6 \mathrm{M}) \text {, } \\
52.7 \% \text { in UDysRS } \\
(6 \mathrm{M}), 39.1 \% \\
\text { reduction in UPDRS } \\
\text { III on medication } \\
(12 \mathrm{M}), 42.7 \% \text { in } \\
\text { UDysRS }(12 \mathrm{M})\end{array}$ & $\begin{array}{l}\text { One patient had } \\
\text { dysarthria and } \\
\text { hemiparesis due } \\
\text { to unexpected } \\
\text { lesion in } \\
\text { the anterior } \\
\text { thalamus }\end{array}$ \\
\hline $\begin{array}{l}\text { Martínez- } \\
\text { Fernández } \\
\text { et al. }{ }^{40)}\end{array}$ & 2018 & Spain & 10 & 6 & $\begin{array}{l}\text { Medically } \\
\text { uncontrolled } \\
\text { motor symptoms }\end{array}$ & STN & $\begin{array}{l}53 \% \text { reduction of } \\
\text { MDS-UPDRS III in } \\
\text { off period }(6 \mathrm{M}) \text {, } \\
47 \% \text { reduction of } \\
\text { MDS-UPDRS III in } \\
\text { on period }(6 \mathrm{M})\end{array}$ & $\begin{array}{l}\text { Dyskinesia, } \\
\text { speech } \\
\text { disturbance, gait } \\
\text { disturbance }\end{array}$ \\
\hline $\begin{array}{l}\text { Martínez- } \\
\text { Fernández } \\
\text { et al. }{ }^{43)}\end{array}$ & 2020 & Spain & $40 \mathrm{RCT}$ & 4 & $\begin{array}{l}\text { Medically } \\
\text { uncontrolled } \\
\text { motor symptoms }\end{array}$ & STN & $\begin{array}{l}49.2 \% \text { reduction in } \\
\text { mean MDS-UPDRS } \\
\text { III }(4 \mathrm{M}) \text {, sham, } 9 \%\end{array}$ & $\begin{array}{l}\text { Dyskinesia } \\
\text { (chorea, ballism), } \\
\text { motor weakness, } \\
\text { speech } \\
\text { disturbance, gait } \\
\text { disturbance }\end{array}$ \\
\hline
\end{tabular}

CRST: clinical rating scale of tremor, F/U: follow-up, GPi: globus pallium interna, M: month, MDS: Movement Disorder Society, MR: magnetic resonance, N of Pts: number of patients, PD: Parkinson's disease, PTT: pallidothalamic tractotomy, Pub: publication, RCT: randomized controlled trial, STN: subthalamic nucleus, UDysRS: Unified Dyskinesia Rating Scale, UPDRS: Unified Parkinson's Disease Rating Scale, Vim: ventral intermediate.

\section{Conclusion}

MRgFUS is the latest minimally invasive stereotactic surgical procedure, and thalamotomy using this modality is effective and safe for patients with ET and PD. The advantages of this treatment include its non-invasiveness, continuous intraoperative monitoring of symptoms and images, and fine adjustment of the target. Clinical outcomes of MRgFUS such as tremor control rates were similar to those in other modalities, including DBS, RF, and radiosurgery. The adverse effects are usually transient and acceptable. Long-term outcomes should be evaluated in future studies. This procedure was recently covered by the health insurance in Japan. To perform it safely and effectively, the physician needs to understand the technological aspects of this treatment, including its physiological principles. Additionally, physicians should provide sufficient information to the patient to explain the advantages and disadvantages of MRgFUS compared to other modalities, discuss them well, and choose the appropriate treatment.

\section{Acknowledgments}

We would like to thank Dr. Hirohisa Kawahara and all staff of Radiosurgery and Focused Ultrasound 
Surgery Center in Nagoya Kyoritsu Hospital for their help in managing the treatment using MRgFUS. We also thank two neurologists in Nagoya University Hospital, Dr. Takashi Tsuboi and Dr. Masashi Suzuki, who have contributed for pre- and postoperative neurological evaluation in the patients with tremor. This study was supported by a Grant-in-Aid for Scientific Research (KAKENHI, no. 17K10891). This study was presented in part at the 60th Annual Meeting of the Japanese Society for Stereotactic and Functional Neurosurgery.

\section{Conflicts of Interest Disclosure}

All authors declare that there are no conflicts of interest (COIs) regarding this article according to the criteria of the Japan Neurosurgical Society. They completed the self-reported registration of their COI status to the society.

\section{References}

1) Insightec Japan: News and events. Press-releases. https://www.insightec.co.jp/news-events/press-releases (Accessed on $2020 \mathrm{Sep} 1$ )

2) Benabid AL, Pollak P, Gervason C, et al.: Long-term suppression of tremor by chronic stimulation of the ventral intermediate thalamic nucleus. Lancet 337: 403-406, 1991

3) Elias WJ, Huss D, Voss T, et al.: A pilot study of focused ultrasound thalamotomy for essential tremor. $N$ Engl J Med 369: 640-648, 2013

4) Elias WJ, Lipsman N, Ondo WG, et al.: A randomized trial of focused ultrasound thalamotomy for essential tremor. $N$ Engl J Med 375: 730-739, 2016

5) Kantzanou M, Korfias S, Panourias I, Sakas DE, Karalexi MA: Deep brain stimulation-related surgical site infections: a systematic review and meta-analysis. Neuromodulation 24: 197-211, 2021

6) Pollet B: Chapter 1, in Power Ultrasound in Electrochemistry: From Versatile Laboratory Tool to Engineering Solution. Hoboken, John Wiley \& Sons, 2012.

7) Ghanouni P, Pauly KB, Elias WJ, et al.: Transcranial MRI-guided focused ultrasound: a review of the technologic and neurologic applications. AJR Am J Roentgenol 205: 150-159, 2015

8) Clement GT, White PJ, King RL, McDannold $\mathrm{N}$, Hynynen K: A magnetic resonance imagingcompatible, large-scale array for trans-skull ultrasound surgery and therapy. J Ultrasound Med 24: 1117-1125, 2005

9) Kaye EA, Pauly KB: Adapting MRI acoustic radiation force imaging for in vivo human brain focused ultrasound applications. Magn Reson Med 69: 724-733, 2013
10) Sun T, Zhang Y, Power C, et al.: Closed-loop control of targeted ultrasound drug delivery across the blood-brain/tumor barriers in a rat glioma model. Proc Natl Acad Sci U S A 114: E10281-E10290, 2017

11) Burgess A, Dubey S, Yeung S, et al.: Alzheimer disease in a mouse model: MR imaging-guided focused ultrasound targeted to the hippocampus opens the bloodbrain barrier and improves pathologic abnormalities and behavior. Radiology 273: 736-745, 2014

12) Lipsman N, Meng Y, Bethune AJ, et al.: Bloodbrain barrier opening in Alzheimer's disease using MR-guided focused ultrasound. Nat Commun 9: 2336, 2018

13) Speelman JD, Schuurman R, de Bie RM, Esselink RA, Bosch DA: Stereotactic neurosurgery for tremor. Mov Disord 17: S84-S88, 2002

14) Kobayashi K, Katayama $\mathrm{Y}$, Kasai M, Oshima H, Fukaya C, Yamamoto T: Localization of thalamic cells with tremor-frequency activity in Parkinson's disease and essential tremor. Acta Neurochir Suppl 87: 137-139, 2003

15) Milosevic L, Kalia SK, Hodaie M, Lozano AM, Popovic MR, Hutchison WD: Physiological mechanisms of thalamic ventral intermediate nucleus stimulation for tremor suppression. Brain 141: 2142-2155, 2018

16) Nowacki A, Debove I, Rossi F, et al.: Targeting the posterior subthalamic area for essential tremor: proposal for MRI-based anatomical landmarks. J Neurosurg 131: 820-827, 2018

17) Blacker HM, Bertrand C, Martinez N, Hardy J, Molina-Negro P: Hypotonia accompanying the neurosurgical relief of essential tremor. J Nerv Ment Dis 147: 49-55, 1968

18) Wintermark M, Druzgal J, Huss DS, et al.: Imaging findings in MR imaging-guided focused ultrasound treatment for patients with essential tremor. AJNR Am J Neuroradiol 35: 891-896, 2014

19) 2019 New medical device fair use standard (MRguided focused ultrasound surgery) development project report: The Japan Neurosurgical Society new medical device fair use standard development project (MR-guided focused ultrasound surgery) committee, 2019

20) Chang WS, Jung HH, Zadicario E, et al.: Factors associated with successful magnetic resonanceguided focused ultrasound treatment: efficiency of acoustic energy delivery through the skull. J Neurosurg 124: 411-416, 2016

21) Sinai A, Nassar M, Eran A, et al.: Magnetic resonanceguided focused ultrasound thalamotomy for essential tremor: a 5-year single-center experience. J Neurosurg 133: 417-424, 2020

22) Boutet A, Gwun D, Gramer R, et al.: The relevance of skull density ratio in selecting candidates for transcranial MR-guided focused ultrasound. J Neurosurg 132: 1785-1791, 2019

23) D'Souza M, Chen KS, Rosenberg J, et al.: Impact of skull density ratio on efficacy and safety of magnetic 
resonance-guided focused ultrasound treatment of essential tremor. J Neurosurg 132: 1392-1397, 2019

24) Fukutome K, Kuga Y, Ohnishi H, Hirabayashi H, Nakase H: What factors impact the clinical outcome of magnetic resonance imaging-guided focused ultrasound thalamotomy for essential tremor? J Neurosurg 134: 1618-1623, 2020

25) Abe K, Horisawa S, Yamaguchi T, et al.: Focused ultrasound thalamotomy for refractory essential tremor: a Japanese multicenter single-arm study. Neurosurgery 88: 751-757, 2021

26) Bhatia KP, Bain P, Bajaj N, et al.: Consensus statement on the classification of tremors. From the task force on tremor of the International Parkinson and Movement Disorder Society. Mov Disord 33: 75-87, 2018

27) Louis ED, Bares M, Benito-Leon J, et al.: Essential tremor-plus: a controversial new concept. Lancet Neurol 19: 266-270, 2020

28) Steffen JK, Jergas H, Petry-Schmelzer JN, et al.: Thalamic deep brain stimulation in essential tremor plus is as effective as in essential tremor. Brain Sci 10: 970,2020

29) Bond AE, Shah BB, Huss DS, et al.: Safety and efficacy of focused ultrasound thalamotomy for patients with medication-refractory, tremor-dominant Parkinson disease: a randomized clinical trial. JAMA Neurol 74: 1412-1418, 2017

30) Chang JW, Park CK, Lipsman N, et al.: A prospective trial of magnetic resonance-guided focused ultrasound thalamotomy for essential tremor: results at the 2-year follow-up. Ann Neurol 83: 107-114, 2018

31) Meng Y, Solomon B, Boutet A, et al.: Magnetic resonance-guided focused ultrasound thalamotomy for treatment of essential tremor: a 2-year outcome study. Mov Disord 33: 1647-1650, 2018

32) Park YS, Jung NY, Na YC, Chang JW: Four-year follow-up results of magnetic resonance-guided focused ultrasound thalamotomy for essential tremor. Mov Disord 34: 727-734, 2019

33) Krishna V, Sammartino F, Cosgrove R, et al.: Predictors of outcomes after focused ultrasound thalamotomy. Neurosurgery 87: 229-237, 2020

34) Pineda-Pardo JA, Urso D, Martínez-Fernández R, et al.: Transcranial magnetic resonance-guided focused ultrasound thalamotomy in essential tremor: a comprehensive lesion characterization. Neurosurgery 87: 256-265, 2020

35) Kapadia AN, Elias GJB, Boutet A, et al.: Multimodal MRI for MRgFUS in essential tremor: post-treatment radiological markers of clinical outcome. J Neurol Neurosurg Psychiatry 91: 921-927, 2020

36) Yamamoto K, Ito H, Fukutake S, et al.: Factors associated with heating efficiency in transcranial focused ultrasound therapy. Neurol Med Chir (Tokyo) 60: 594-599, 2020

37) Magara A, Bühler R, Moser D, Kowalski M, Pourtehrani P, Jeanmonod D: First experience with
MR-guided focused ultrasound in the treatment of Parkinson's disease. J Ther Ultrasound 2: 11, 2014

38) Nauta WJ, Mehler WR: Projections of the lentiform nucleus in the monkey. Brain Res 1: 3-42, 1966

39) Jung NY, Park CK, Kim M, Lee PH, Sohn YH, Chang JW: The efficacy and limits of magnetic resonance-guided focused ultrasound pallidotomy for Parkinson's disease: a Phase I clinical trial. J Neurosurg 130: 1853-1864, 2019

40) Martínez-Fernández R, Rodríguez-Rojas R, Del Álamo $\mathrm{M}$, et al.: Focused ultrasound subthalamotomy in patients with asymmetric Parkinson's disease: a pilot study. Lancet Neurol 17: 54-63, 2018

41) Chen CC, Lee ST, Wu T, Chen CJ, Huang CC, Lu CS: Hemiballism after subthalamotomy in patients with Parkinson's disease: report of 2 cases. Mov Disord 17: 1367-1371, 2002

42) Merello M, Perez-Lloret S, Antico J, Obeso JA: Dyskinesias induced by subthalamotomy in Parkinson's disease are unresponsive to amantadine. J Neurol Neurosurg Psychiatry 77: 172-174, 2006

43) Martínez-Fernández R, Máñez-Miró JU, RodríguezRojas R, et al.: Randomized trial of focused ultrasound subthalamotomy for Parkinson's disease. $N$ Engl J Med 383: 2501-2513, 2020

44) Dallapiazza RF, Lee DJ, De Vloo P, et al.: Outcomes from stereotactic surgery for essential tremor. $\mathrm{J} \mathrm{Neu-}$ rol Neurosurg Psychiatry 90: 474-482, 2019

45) Obwegeser AA, Uitti RJ, Turk MF, Strongosky AJ, Wharen RE: Thalamic stimulation for the treatment of midline tremors in essential tremor patients. Neurology 54: 2342-2344, 2000

46) Sydow O, Thobois S, Alesch F, Speelman JD: Multicentre European study of thalamic stimulation in essential tremor: a six year follow up. J Neurol Neurosurg Psychiatry 74: 1387-1391, 2003

47) Zirh A, Reich SG, Dougherty PM, Lenz FA: Stereotactic thalamotomy in the treatment of essential tremor of the upper extremity: reassessment including a blinded measure of outcome. J Neurol Neurosurg Psychiatry 66: 772-775, 1999

48) Akbostanci MC, Slavin KV, Burchiel KJ: Stereotactic ventral intermedial thalamotomy for the treatment of essential tremor: results of a series of 37 patients. Stereotact Funct Neurosurg 72: 174-177, 1999

49) Blomstedt P, Hariz GM, Hariz MI, Koskinen LO: Thalamic deep brain stimulation in the treatment of essential tremor: a long-term follow-up. Br J Neurosurg 21: 504-509, 2007

50) Pahwa R, Lyons KE, Wilkinson SB, et al.: Long-term evaluation of deep brain stimulation of the thalamus. J Neurosurg 104: 506-512, 2006

51) Fenoy AJ, Simpson RK: Risks of common complications in deep brain stimulation surgery: management and avoidance. J Neurosurg 120: 132-139, 2014

52) Kim SJ, Roh D, Jung HH, Chang WS, Kim CH, Chang JW: A study of novel bilateral thermal capsulotomy 
with focused ultrasound for treatment-refractory obsessive-compulsive disorder: 2-year follow-up. J Psychiatry Neurosci 43: 327-337, 2018

53) Horisawa S, Yamaguchi T, Abe K, et al.: A single case of MRI-guided focused ultrasound ventro-oral thalamotomy for musician's dystonia. J Neurosurg 131: 384-386, 2018

54) Krishna V, Sammartino F, Rezai A: A review of the current therapies, challenges, and future directions of transcranial focused ultrasound technology: advances in diagnosis and treatment. JAMA Neurol 75: $246-254,2018$

Corresponding author: Satoshi Maesawa, MD, PhD Brain and Mind Research Center, Nagoya University, Department of Neurosurgery, Nagoya University School of Medicine, 65 Tsurumaicho, Showa-ku, Nagoya, Aichi 466-8550, Japan.

e-mail: smaesawa@med.nagoya-u.ac.jp 